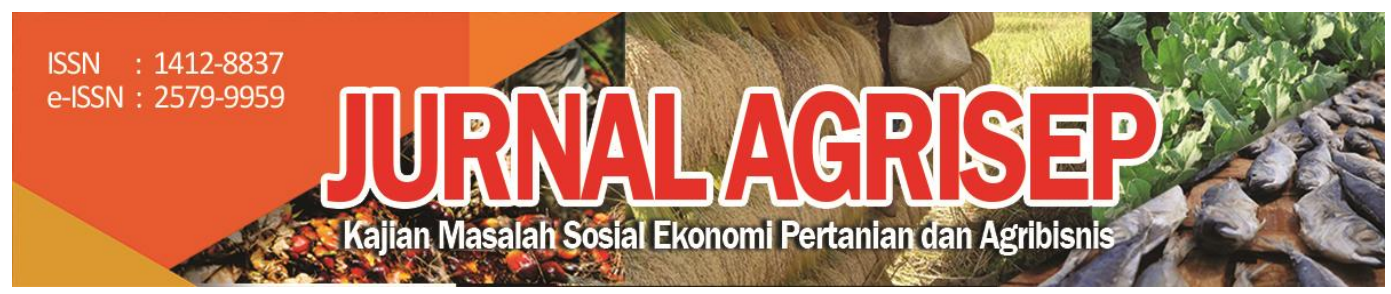

DOI: 10.31186/jagrisep.20.2.367-380

\title{
ANALYSIS OF THE MARKETING EFFICIENCY OF THE RED CURLY CHILI (Capsicum annuum L.) IN KEPAHIANG DISTRICT
}

\section{Analisa Efisiensi Pemasaran Cabe Merah Keriting (Capsicum annuum L.) di Kabupaten Kepahyang}

\author{
Bagus Dwi Pranata1); Redy Badrudin $\left.{ }^{2}\right)$; Mostopa Romdhon ${ }^{3)}$ \\ 1,2,3) Study Program of Agribusiness, Faculty of Agriculture, University of \\ Bengkulu, Bengkulu, Indonesia \\ Email : redybd11@gmail.com
}

\begin{abstract}
This Research is conducted in Kepahiang Regency. The location of the study is selected purposely (deliberately) by considering that the area is one of the production centers of curly red chili in Bengkulu Province. The purpose of this study is to analyze the marketing efficiency performed by the marketing agents of curly red chili in Kepahiang Regency. The samples in this study are 37 chili farmers, 11 collectors, 4 intercity traders, and 12 retailers who sell to the final consumer. This study uses primary data. Marketing efficiency is analyzed through marketing channel, analysis of marketing margin, and Farmer's share, as the efficiency measurement scale. The findings of this study indicate that the marketing of curly red chilies in Kepahiang Regency is categorized as Efficient.
\end{abstract}

Keywords: marketing, red chili, efficiency, marketing margin, farmer's share.

\section{ABSTRACT}

Penelitian ini dilakukan di Kabupaten Kepahiang. Lokasi penelitian dipilih secara sengaja (sengaja) dengan mengingat daerah tersebut merupakan salah satu sentra produksi cabai merah keriting di Provinsi Bengkulu. Tujuan dari penelitian ini adalah untuk menganalisis efisiensi pemasaran yang dilakukan oleh agen pemasaran cabai merah keriting di Kabupaten Kepahiang. Sampel dalam penelitian ini adalah 37 petani cabai, 11 pengepul, 4 pedagang antar kota, dan 12 pengecer yang menjual ke konsumen akhir. Penelitian ini menggunakan data primer. Efisiensi pemasaran dianalisis melalui saluran pemasaran, analisis margin pemasaran, dan Farmer's share, sebagai skala 
pengukuran efisiensi. Temuan penelitian ini menunjukkan bahwa pemasaran cabai merah keriting di Kabupaten Kepahiang dikategorikan Efisien.

Kata kunci: pemasaran, cabai merah, efisiensi, margin pemasaran, harmer's share.

\section{INTRODUCTION}

According to Saragih (2001), Indonesia is an agrarian country where agricultural development has a strategic position with activities related to agriculture based on plants food horticulture. Other than involving the biggest labor in the production, this sector's product is also the staple food ingredients for national consumption. In terms of business, economic activities which are based on food crops and horticulture are the largest business activities widespread throughout Indonesia.

Chili is a horticulture commodity that is consumed by all circles in Indonesia. Bengkulu Province is one of the areas which has the potential to develop chili commodity with planting spread from the lowlands to the highlands, which shows that the chili plants have good adaptability, moreover, with a typical spicy taste that makes this commodity always in high demand. Based on the Ministry of Agriculture (2018)1, the breadth area of harvested big chili in Indonesia in 2018 was 136,857 hectares with a large chili production level of 1,206,737 tons.

According to Nauly (2016), the increasing agricultural commodity production, including red chili, needs to be accompanied by an improvement on on-farm (Makausi,2021) and its marketing system (onfarm); therefore,ifarmers as producers of this commodity are expected to be able to get an adequate share of price to increase their farming business. An efficient marketing system must be able to fulfill two requirements, namely: (1) the creation of an efficient product supply chain through marketing institutions from upstream to downstream, (2) the ability to distribute a fair share of remuneration from the total final consumer price to all parties involved from production to marketing activities.

Red chili (Capsicum annuum L.) agribusiness has opportunities in the national economy. Red chili has a high fluctuation rate. This fluctuation occurs due to the influence of an unbalanced comparison of supply and demand that usually happens during the harvest season. Besides that, the size of the price margin is influenced by the number of traders involved; the more levels of the traders involved, then the price

368 | Bagus Dwi Pranata; Redy Badrudin; Mostopa Romdhon; Analysis ... 
margin between farmers and retailers tends to be higher. By knowing the right and good supply chain management and marketing strategies, the margin price can be minimized in order to get maximum profit.

There are four factors as indicators of marketing efficiency: marketing margins, prices at the consumer level, the availability of physical marketing facilities, and market competition. How to analyze efficiency can be seen from the organization of the commodity market, which includes the structure, behavior, and performance of the market. The longer the supply channel, the higher the consumer price. The longer the channel, the more inefficient the price received by consumers. This research is expected to consider market managers to establish a more efficient system by knowing efficient supply channels. Therefore, it is necessary to study the analysis of the red chili supply chain efficiency analysis (Hasyim 2012).

Based on the description of the problems above, the authors are interested in conducting research to identify and analyze the supply chain mechanism of curly red chili, as well as the level of supply chain efficiency carried out by curly red chili agribusiness agents in Kepahiang Regency.

\section{RESEARCH METHODS}

\section{Method of Determining Location and Respondent}

Determination of the location in this study was carried out purposely (deliberately), namely, sampling in Kepahiang Regency with the consideration that the area is one of the centers of curly red chili production in Bengkulu Province. This research was conducted on February 29 - March 9, 2020 in Kepahiang Regency. The method of determining the sample is by using the technique of Simple Random Sampling and Snowball sampling. The research was carried out by conducting field surveys of curly red chili commodities from farmers, collectors, suppliers, to retailers. Simple Random Sampling method was used to determine the sample suppliers, there were in total of 37 curly chili farmers involved. The Snowball sampling method was used to take samples of institutions or links involved in the supply chain of curly red chili commodities in Kepahiang Regency, where samples obtained were 11 collectors, 4 inter-city traders, 12 retailers. Whereas the respondents were obtained based on the information from previous respondents by following the supply flow of curly red chili. 


\section{Method of Data Collection and Analysis}

The types of data collected in this study are primary data and secondary data. Primary data are data obtained directly from respondents through direct interviews using a list of questions (questionnaires) that have been prepared in advance, while secondary data are obtained from various literatures, agencies, and institutions related to this research. Data analysis in this research is quantitative analysis to process primary and secondary data. This analysis focuses on field surveys by observing and interviewing a sample of respondents. Quantitative methods are carried out to answer problems regarding the supply chain efficiency of curly red chili commodities by using an efficiency measurement scale.

\section{Analysis of Margin and Marketing Efficiency}

Marketing efficiency can be known by calculating the marketing margin. The trading chain is said to be more efficient if the marketing margin is getting smaller. Mathematically, the marketing margin according to Sudiyono (2001) can be expressed using the marketing margin formula as follows

$$
\mathrm{M}=\mathrm{Pr}-\mathrm{Pf}
$$

where $\mathrm{M}$ denotes Marketing Margin; pr represents Price at retailer level (retail price), and Pf is Price at farm level (farm gate price)

According to Widayaningsih et. Al. (2012) and Kusmawati, et. al. (2017), the decision-making criteria in determining an efficient supply chain is viewed based on the size of the margin distribution. It is efficient if $S k i>S b i$, and inefficient if $S k i<S b i$ in which $S b i$ denotes an average cost margin for red chili for the i-th institution (\%) and $S k i$ is an average profit margin for red chili for the $\mathrm{i}$-th institution (\%). The distribution of the marketing margin consists of the profit margin $(\mathrm{Ki})$ obtained and the cost margin $(\mathrm{Bi})$ incurred by the marketing agency: as well as Selling price of the product at the level of the i marketing agency $(\mathrm{Hjp})$

$$
\begin{aligned}
& S b i=\frac{B i}{H j p} \times 100 \%, \text { and } \\
& S k i=\frac{K i}{H j p} \times 100 \%
\end{aligned}
$$

Farmer's share can be used to calculate marketing efficiency. Farmer's share is the ratio between the price received by farmers $(P f)$ and the price paid $(P k)$ by the final consumer. Determination of trading efficiency through farmer's share can be done with decision making criteria if the farmer's share value obtained is more than $70 \%$ then it is said to be efficient, and vice versa if 
the farmer's share value is less than $70 \%$, it is said to be inefficient (Prayitno et al., 2013). Market share or income for farmers (farmer's share) is calculated by:

$$
F S=\frac{P f}{P k} \times 100 \%
$$

\section{RESULTS AND DISCUSSION}

\section{Channels, Marketing Margin Efficiency, and Share Value of Curly Red Chili in Kepahiang District}

Determination of the purchase price and selling price is used to calculate the marketing margin of each channel in the supply chain of curly red chili commodities in Kepahiang Regency. In the supply chain of curly red chili commodities in Kepahiang Regency, there are three mechanisms in the supply chain. Clearly, the results in the form of a structure in the supply chain of curly red chili commodities in Kepahiang Regency are depicted in Figure 1.

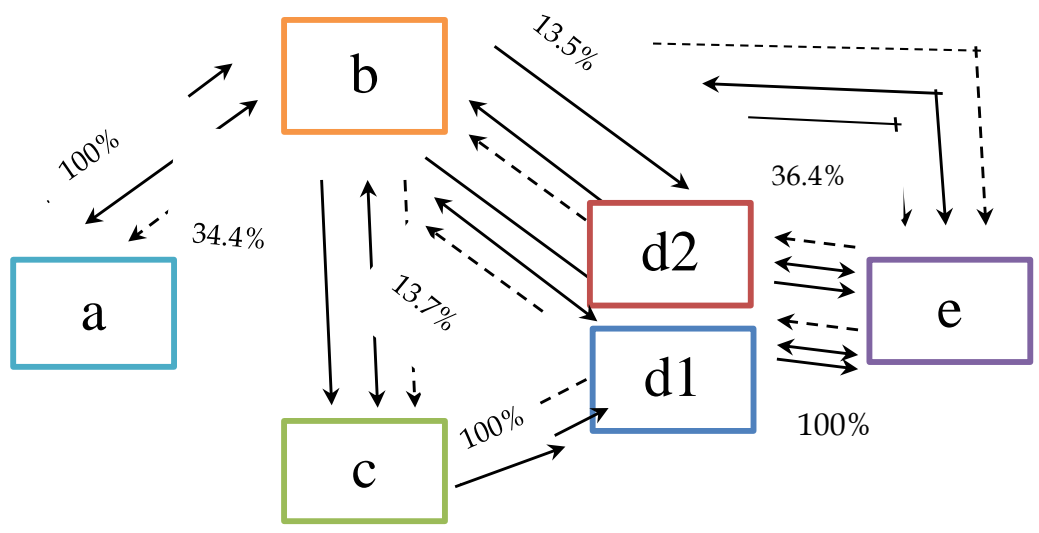

Figure 1.

The Curly Red Chili Trading Channel in Kepahiang District Information :

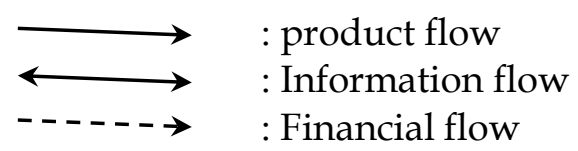

a is Farmer, d1 is Retailer outside Kab. Kepahiang, b is Collecting traders, d2 is Retailer in Kab. Kepahiang, c is Inter-city traders, and e is Final Consumers

Based on Figure 1. on the flow pattern in the supply chain of curly red chili in Kepahiang Regency, it shows that the supply chain mechanism for the curly red chili commodity in Kepahiang Regency is generally divided into 3 types, namely, product flow, information flow, and financial flow. There are 5 
link members involved in the supply chain mechanism for curly red chili in Kepahiang Regency. In determining the order of the curly red chili supply chain channel in Figure 1., the percentage is based on the respondent's approach, totaling 64 respondents. Product flow from (a) to $(b)$ is $100 \%$, from (b) to (c) is $3644 \%$, from (b) to (d) is $27.2 \%$ ( $\mathrm{d} 1$ is $13.7 \%$, d2 is $13,5 \%$ ), from $b$ to $e$ as much as $36.4 \%$, from $\mathrm{c}$ to $\mathrm{d}$ as much as $100 \%$, from $\mathrm{d}$ to e as much as $100 \%$.

In the research area there are several patterns of marketing channels for curly red chilies in Kepahiang Regency which have been sorted based on the percentage of respondents' approaches, namely as follows:

1. Farmers - Collectors Traders - Final consumers

2. Farmer - Collector Trader - Intercity Trader - Retailer - Final Consumer.

3. Farmer - Trader Collector - Retailer Trader (Outside Kepahiang) Consumer

4. Farmer - Collector Trader - Retailer (In Kepahiang) - Final consumer. These findings indicate that marketing channel of red chilli curly in Kepahyang is relatively long and multifarious. In fact, according to Faiqoh, et al (2021) and Novitarin, et. al. (2020), Saleh et. al. (2020), the shorter chilli marketing in Malang shows that the efficiency of the marketing system indicates higher than in Bengkulu.

Figure 1 maps the pattern of curly red chili marketing channels in Kepahiang Regency. There are four marketing channels in Kepahiang Regency involving 3 marketing institutions, namely farmers (a) village collectors (b), inter-city traders (c), retailers (d) and final consumers (e). In marketing channel $1 \mathrm{zz}$ (which is the main channel), farmers sell curly red chili products to collectors. The number of curly red chilies sold by farmers to collectors is 630 $\mathrm{kg}$ and is paid directly (cash) by collectors. Collecting traders in marketing channel 1 pack curly red chilies using bamboo baskets for sale to consumers who want to buy directly from village collectors. These collectors are quite helpful for farmers in reducing transportation and sack costs, because they already provide these facilities. Information received by farmers on marketing channel 1 is obtained through communication using cellphones to find out the price of red chili in the market and also the quality and quantity of red chili sold by farmers to collectors.

In marketing channel 2, farmers (a) sell their curly red chili products to village collectors (b) and inter-city traders (c) and retailers (d) and final consumers (e). The number of curly red chilies sold by farmers to collectors is 1 $670 \mathrm{~kg}$ and is paid directly (cash). Collecting traders on marketing channel 2 directly pick up curly red chilies themselves from farmers and pack curly red chilies using $50 \mathrm{~kg}$ sacks to be sold to inter-city traders. The curly red chilies are sold to retailers at Lais Market, Sembayat Market, and Pasar Pekan Saturday. The amount of curly red chili marketed by inter-city traders on marketing 
channel 2 is 1 ton. The number of curly red chilies purchased from inter-city traders by retailers on channel 2 is $650 \mathrm{~kg}$. In the marketing channel, 2 farmers, collectors, inter-city traders and retailers exchange information via cellphones regarding the price of chili in the market, delivery schedules, and the quality of red chili.

In marketing channel 3, farmers (a) sell their curly red chili products to village collectors (b), then sell them to retailers outside Kepahiang Regency (d) and then go to final consumers (e). The number of curly red chilies sold by farmers to collectors is $1590 \mathrm{~kg}$. Collecting traders on marketing channel 4 directly pick up curly red chilies themselves from farmers and pack curly red chilies using sacks containing $50 \mathrm{~kg}$ and $80 \mathrm{~kg}$ to be sold to retailers in Bengkulu City. The curly red chilies are sold to retailers in the Panorama market and the Bengkulu City Sunday market. The number of curly red chilies sold by village collectors to retailers on channel 4 is $1050 \mathrm{~kg}$. In the marketing channel, 4 farmers, collectors, and retailers exchange information via cellphones regarding the price of chili in the market, delivery schedules, and also the quality of red chili sold. The results of the calculation of the analysis of marketing margins and farmer's share in each channel can be seen as follows:

Table 1. Marketing Margin, Share Value in Channel 1 of Chili Marketing Red Curly in Kepahiang District.

\begin{tabular}{|c|c|c|c|c|}
\hline \multirow{2}{*}{ No } & \multirow{2}{*}{ Marketing Agency } & \multirow{2}{*}{ Price (IDR/Kg) } & \multicolumn{2}{|c|}{ Shares $(\%)$} \\
\hline & & & Ski & Sbi \\
\hline \multirow[t]{2}{*}{1} & Farmer (a) & & & \\
\hline & Selling price & 30.081 & 92,95 & \\
\hline \multirow[t]{6}{*}{2} & Village Collecting Traders (b) & & & \\
\hline & Selling price & 32.364 & & \\
\hline & Purchase price & 30.081 & & \\
\hline & Transportation costs & 249 & & 0,77 \\
\hline & Labor costs & 1.8 & & 0,72 \\
\hline & Profit & & & \\
\hline \multirow[t]{4}{*}{3} & End consumer $€$ & & & \\
\hline & Purchase price & 32.364 & & \\
\hline & Marketing Margin & 2,283 & & \\
\hline & Total & & 98,51 & 1,49 \\
\hline
\end{tabular}

Source: Primary Data Processed in 2020

In marketing channel 4, farmers (a) sell their curly red chili products to village collectors (b), retailers in Kepahiang Regency (d2), and final consumers (e). The number of curly red chilies sold by farmers to collectors is $960 \mathrm{~kg}$. Collecting traders on marketing channel 3 directly pick up curly red chilies 
themselves from farmers and pack curly red chilies using $50 \mathrm{~kg}$ sacks to be sold to retailers in the Kepahiang market. Village collector traders on channel 3 only sell curly red chilies to traders retailers in the Kepahiang market. The number of curly red chilies sold by village collectors to retailers on channel 3 is $950 \mathrm{~kg}$. In the marketing channel, 3 farmers, collectors, and retailers exchange information via cell phones regarding the price of chili in the market, delivery schedules, and also the quality of red chili sold. Table 1 is channel 1 with the value of the marketing margin for each kilogram of red chili distributed in channel 1 is IDR 2,283. Share profit of $5.562 \%$ and share the cost of $1.49 \%$. This shows that the red chili distribution channel is said to be efficient because the profit share is greater than the cost share and has a farmer's share $92.95 \%$ or more than $70 \%$.

If we look at table 2 carefully, it can be seen that marketing channel 2 with the value of the marketing margin for each kilogram of red chili distributed in channel 1 is $\mathrm{Rp} \mathrm{6,919.} \mathrm{Share} \mathrm{profit} \mathrm{of} 15.4 \%$ and share costs of $3.33 \%$. This shows that the red chili distribution channel is said to be efficient because the profit share is greater than the cost share and has a farmer's share $81.3 \%$ or > $70 \%$

Table 2. Marketing Margin, Share Value on Channel 2, Marketing of Curly Red Chili in Kepahiang Regency.

\begin{tabular}{|c|c|c|c|c|}
\hline \multirow{2}{*}{ No } & \multirow{2}{*}{ Marketing Agency } & \multirow{2}{*}{ Price (IDR/Kg) } & \multicolumn{2}{|c|}{ Shares (\%) } \\
\hline & & & Ski & Sbi \\
\hline \multirow[t]{2}{*}{1} & Farmer (a) & & & \\
\hline & Selling price & 30.081 & 81,3 & \\
\hline \multirow[t]{6}{*}{2} & Village Collecting Traders (b) & & & \\
\hline & Selling price & 32.364 & & \\
\hline & Purchase price & 30.081 & & \\
\hline & Transportation costs & 249 & & 0,67 \\
\hline & Labor costs & 234 & & 0,63 \\
\hline & Profit & 1.8 & 4,86 & \\
\hline \multirow[t]{6}{*}{3} & Intercity Traders @ & & & \\
\hline & Selling price & 34,750 & & \\
\hline & Purchase price & 32,365 & & \\
\hline & Transportation costs & 360 & & 0,97 \\
\hline & Labor costs & 200 & & 0,54 \\
\hline & Profit & 1.826 & 4,94 & \\
\hline \multirow[t]{5}{*}{4} & Retailer (d1) & & & \\
\hline & Selling price & 37,000 & & \\
\hline & Purchase price & 34,750 & & \\
\hline & Retribution Fee & 189 & & 0,51 \\
\hline & Profit & 2.061 & 5,57 & \\
\hline
\end{tabular}

374 | Bagus Dwi Pranata; Redy Badrudin; Mostopa Romdhon; Analysis ... 
End Consumer

3,000

Purchase price

37,000

Marketing Margin

7

Total

96,7

Source: Primary Data Processed in 2020

Farmers in the study area are highly dependent on channels 1 and 2, because both channels add up to $78.2 \%$. Retailers on channel 1 only have a retribution share of $0.51 \%$ with a profit of $5.57 \%$. If the retailer's profit can be reduced, then the price at the final consumer level can be reduced resulting in increasing the farmer's share. Previous researchers also agreed, among others are Adnyasari et al. (2017), Kusmawati et al. (2017), Angraini (2018), Josine, (2018), Rasidin and Raman (2018), Abidin. (2018), Saptana, et al. (2018), and Rani, et al. (2019),) a marketing system is efficient if it meets the requirements.

Table 3 regarding the value of the marketing margin, the margin value for each kilogram of red chili distributed in channel 1 is Rp4.669, share the profit of $11.61 \%$ and share the cost of $1.82 \%$. This concludes that the red chili distribution channel is said to be efficient.

Table 3. Marketing Margin, Share Value on Marketing Channel 3 of Curly Red Chili in Kepahiang Regency.

\begin{tabular}{|c|c|c|c|c|}
\hline \multirow{2}{*}{ No } & \multirow{2}{*}{ Marketing Agency } & \multirow{2}{*}{ Price $(\mathrm{Rp} / \mathrm{Kg})$} & \multicolumn{2}{|c|}{ Shares (\%) } \\
\hline & & & Ski & Sbi \\
\hline \multirow[t]{2}{*}{1} & Farmer (a) & & & \\
\hline & Selling price & 30.081 & 86,6 & \\
\hline \multirow[t]{6}{*}{2} & Village Collecting Traders (b) & & & \\
\hline & Selling price & 32.364 & & \\
\hline & Purchase price & 30.081 & & \\
\hline & Transportation costs & 249 & & 0,72 \\
\hline & Labor costs & 234 & & 0,67 \\
\hline & Profit & 1.8 & 5,18 & \\
\hline \multirow[t]{10}{*}{3} & Retailer (d1) & & & \\
\hline & Selling price & 34,750 & & \\
\hline & Purchase price & 32,365 & & \\
\hline & Retribution Fee & 150 & & 0,43 \\
\hline & Profit & 2.236 & 6,43 & \\
\hline & Retailer (d1) & & & \\
\hline & Selling price & 37,000 & & \\
\hline & Purchase price & 34,750 & & \\
\hline & Retribution Fee & 189 & & 0,51 \\
\hline & Profit & 2.061 & 6,43 & \\
\hline \multirow[t]{2}{*}{4} & End Consumer $€$ & & & \\
\hline & Purchase price & 34,750 & & \\
\hline
\end{tabular}


Based on table 4, it can be seen that the value of the marketing margin for each kilogram of red chili distributed in channel 1 is Rp. 3.919. Share profit of 9.72\%and share the cost of $1.81 \%$. This shows that the red chili distribution channel is said to be efficient because the profit share is greater than the cost share and has a farmer's share $88.47 \%$ or more than 70 percent.

The distribution capacity of channels 3 and 4 amounted to $27.2 \%$. These two channels, although efficient, can be more efficient. The problem is that channel 3 and 4 are the same as channel 2, namely that retailers take too much of the profit, with a retribution fee of $0.4 \%$ but the profit share reaches $4.42 \%$ to $6.43 \%$. This causes the share for farmers to shrink and consumers bear high prices.

Table 4. Marketing Margin, Share Value on marketing channel 4 of Curly Red Chili in Kepahiang Regency.

\begin{tabular}{|c|c|c|c|c|}
\hline \multirow{2}{*}{ No } & \multirow{2}{*}{ Marketing Agency } & \multirow{2}{*}{$\begin{array}{c}\text { Price } \\
(\mathrm{Rp} / \mathrm{Kg})\end{array}$} & \multicolumn{2}{|c|}{ Shares (\%) } \\
\hline & & & Ski & Sbi \\
\hline \multirow[t]{2}{*}{1} & Farmer (a) & & & \\
\hline & Selling price & 30.081 & 88,47 & \\
\hline \multirow[t]{6}{*}{2} & Village Collecting Traders (b) & & & \\
\hline & Selling price & 32.364 & & \\
\hline & Purchase price & 30.081 & & \\
\hline & Transportation costs & 249 & & 0,73 \\
\hline & Labor costs & 234 & & 0,69 \\
\hline & Profit & 1.8 & 5,29 & \\
\hline \multirow[t]{5}{*}{3} & $\begin{array}{l}\text { Retailer outsid the District. } \\
\text { Kepahiang (d2) }\end{array}$ & 34,000 & & \\
\hline & Purchase price & 32,364 & & \\
\hline & Selling price & 133 & & 0,39 \\
\hline & Retribution Fee & 1.503 & & \\
\hline & Profit & 34,000 & 4,42 & \\
\hline \multirow[t]{4}{*}{4} & End Consumer $€$ & & & \\
\hline & Purchase price & 34,000 & & \\
\hline & Marketing Margin & 4 & & \\
\hline & Total & & 98,19 & 1,81 \\
\hline
\end{tabular}

Source: Primary Data Processed in 2020

376 | Bagus Dwi Pranata; Redy Badrudin; Mostopa Romdhon; Analysis ... 
According to Prayitno, A (2013), Tubagus, et al. (2016), Adnyasari, et al. (2017), Kusmawati, (2017), Agustin, M. et al, (2018), Angraini (2018), Josine, (2018), Rasidin and Raman (2018), Abidin, (2018), Saptana, et al (2018), Rani, Nabila, M, et al. (2019), Saputro (2019), and Erviana, et. al. (2020) the higher cost marketing shows that the efficiency of the marketing system is lower. By conceptual, a marketing system can be considered efficient when it is in the production and supply chain activities of a product. Meanwhile, according to Jannah (2018), the value of the farmer's share is calculated based on the comparison of the price at the farmer level as a producer with the price at the final consumer level of red chili. Farmer's share value of more than 70 percent is efficient, and if it is less than 70 percent, it is not efficient. On the other hand, the marketing of chili is not yet efficiently reported by Setiawan, et. al. (2020).

The four channels are efficient, but out of the four marketing channels of curly red chili above, the most efficient marketing channel is channel 1 . Channel 1 is said to be efficient because the share for farmers is larger, the marketing margin is the smallest than the other channels.

In the concern of benefit for farmers, it need to unity the farmers ini more power bargaining by accomplishing the grup, sach as farger groups, cooperative (Dua Asa, et al. 2020), the farmers dealing with auxion marketing model (.Agustin, et. al. 2021), better marketing horizontal integration (Samantha, et al.. 2021), (Ningsih, et. al. 2020).

\section{CONCLUSIONS AND RECOMMENDATION}

The marketing channel of curly red chili in Kepahiang Regency involves farmers as suppliers of curly red chili and marketing institutions, namely: collector traders, inter-city traders, and trader retailers. There are 4 patterns of curly red chili marketing channels in Kepahiang Regency. Channel most marketing efficient is channel I that is from Farmer -Collecting -Merchants Final Consumers.

It is expected to be able to improve marketing efficiency, especially for retailers who take too large a profit share by providing price information to final consumers through price information boards or media, so that final consumers know the price of curly red chili according to perfectly competitive market requirements, one of which is the buyers and sellers both know about the development of curly red chili prices. 


\section{REFERENCE.}

Abidin, Z. 2018. Analisis Rantai Pasok Cabe Di Kota Kendari. Jurnal Mega Aktiva. 7(1): 20-29

Adnyasari, P, S., Dewi, R,K., dan Susrusa, K, B. 2017. Analisis Sistem Tataniaga Cabai Merah Di Desa Besakih, Kecamatan Rendang, Kabupaten Karangasem. E-Jurnal Agribisnis Dan Agrowisata. 6(4): 218-225

Agustin, M., Siswadi, B., dan Hindarti, S. 2018. Analisis Rantai Pasok (Supply Chain) Cabai Merah Di Sta Mantung Kecamatan Pujon Kabupaten Malang. Jurnal Berkala Ilmiah Pertanian.7(1): 1-8

Agustin, R, D., Nugroho, A, D., dan Masyhuri. 2021. Kepuasan Petani Terhadap Layanan Pasar Lelang Cabai Sidodadi Di Kabupaten Kulon Progo. Jurnal Sosial Ekonomi Pertanian dan Agribisnis. 17(2): 174 - 184

Angraini, A. 2018. Analisis Pemasaran Cabai Merah Keriting Di Desa Sidera Kecamatan Sigi Biromaru Kabupaten Sigi. E-Jurnal Agrotekbis. 2(6) : 667-675.

Asrianti, E. 2016. Analisis Pemasaran Usahatani Cabai Merah Keriting Di Desa Maku Kecamatan Dolo Kabupaten Sigi. E-Jurnal Agrotekbis. 2(6) : 660666

Asa, E, F, R, D., Munanto, T, S., dan Astuti, R, S. 2020. Peran Kelompok Tani Terhadap Pemasaran Cabai (Capsicum Annum L) Ke Pasar Lelang. Jurnal Ilmu-Ilmu Pertanian Politeknik Pembangunan Pertanian YogyakartaMagelang. 27(2): 11-18

Erviana, V., Syaukat, Y., dan Fariyanti, A. 2020. Analisis Transmisi Harga Cabai Merah Besar Di Provinsi Jawa Barat. Jurnal Ekonomi Pertanian Dan Agribisnis. 4(1): 77-86

Faiqoh, I., Susilowati, D., Sudjoni, M, N. 2021. Analisis Pemasaran Cabai Merah (Capsium Annum) Pada Kelompok Tani Sumber Makmur Di Kelurahan Merjosari Kecamatan Lowokwaru Kota Malang. Jurnal Sosial ekonomi Pertanian dan Agribisnis. 9(2): 1-14

Hasyim, A. I. 2012. Pengantar Tataniaga Pertanian. Bandar Lampung : Universitas Lampung. 253 Pages

Jannah, M dan Hani, E, S. 2018. Analisis Rantai Pasokan Cabai Merah Di Kabupaten Banyuwangi. Prosidimg Seminar Nasional Pembangunan Pertanian dan Peran Pendidikan Tinggi Agribisnsis: Peluang E Tantangann di Era Industri 4.0 Universitas Jember 3 November 2018: 179-191

Josine, N, A., Lyndon, R, J, P, dan Pakasi, C, B, D. 2018. Analisis Rantai Pasok Komoditi Cabai Rawit Di Kota Manado. Jurnal Agri-Sosioekonomi Unsrat. 14(1): 207-214

Kusmawati, L., Herdiansah, D., dan Hardiyanto, T. 2017. Analisis Saluran Pemasaran Cabai Merah Varietas Tanjung 2 (Suatu Kasus Di

Kelurahan Tamanjaya Kecamatan Tamansari Kota Tasikmalaya). Jurnal Ilmiah Mahasiswa Agroinfo Galuh. 4(1): 677-682

378 | Bagus Dwi Pranata; Redy Badrudin ; Mostopa Romdhon; Analysis ... 
Makausi, J, B., Suzana, B, O, L., dan Kumaat, R, M. 2021. Analisis Keuntungan Usahatani Cabai Merah Keriting Cv Farel Di Kelurahan Kakaskasen di Kecamatan Tomohon Utara Kota Tomohon. Jurnal Agribisnis dan Pengembangan Pedesaan. 3(2): 270 - 275

Nauly, D. 2016. Fluktuasi Dan Disparitas Harga Cabai Di Indonesia. Jurnal Agrosains Dan Teknologi. 1(1): 57-69

Ningsih, I, W., Wahyuni, I., dan Malik, A. 2020. Analisis Rantai Pasok Cabai Merah Di Kota Jambi Provinsi Jambi. Journal Of Agribusiness And Local Wisdom. 3(2): 87-97

Novitarini, E. 2020. Analisis Pemasaran Usahatani Cabai Merah Keriting Di Kelurahan Sei Selincah Kecamatan Kalidoni Palembang. Jurnal Ilmu Pertanian Agronitas. 2(2): 7-16

Prayitno, A, B., Hasyim, A, B., dan Situmorang, S. 2013. Efisiensi Pemasaran Cabai Merah Di Kecamatan Adiluwih Kabupaten Pringsewu Provinsi Lampung. Jurnal Ilmu Ilmu Agrbisnis. 1(1): 53-59

Rani, N, M., Taufikurahman, R., dan Lenggono, S. 2019. Analisis Rantai Pasok Cabai Merah Keriting (Capsicum Annuum L) Di Dki Jakarta (Studi Kasus Di Pasar Induk Kramat Jati). Journal Of Economic. 2(1): 15-26

Rasidin., Yusriadi., dan Rahman. 2018. Analisis Pendapatan Dan Efisiensi Pemasaran Cabai Merah Di Kecamatan Watangpulu Kabupaten Sidrap. Jurnal Pendidikan Teknologi Pertanian. 4 : 84- 91

Tubagus, L, S., Mangantar, M., dan Tawas, H, N. 2016. Analisis Rantai Pasokan (Supply 'Chain) Komoditas Cabai Rawit Di Kelurahan Kumelembuai Kota Tomohon. Jurnal Riset Ekonomi, Manajemen, Bisnis dan Akuntansi. 4(2): 613-621

Saleh, L. 2020. Analisis Efisiensi Saluran Tataniaga Cabai Di Kecamatan Onembute Kabupaten Konawe. Surya Agritama. 9(1): 49-61

Samantha, K., Tarno., dan Rahmawati, R. 2021. Analisis Integrasi Spasial Pasar Cabai Merah Keriting Di Jawa Tengah Dengan Metode Vector Error Correction Model. Jurnal Gaussian. 10(2): 190-199

Saptana., Muslim, C., dan Susilowati, S, H. 2018. Manajemen Rantai Pasok Komoditas Cabai Pada. Agroekosistem Lahan Kering Di Jawa Timur. Analisis Kebijakan Pertanian. 16(1): 19-41

Saragih. 2010. Kumpulan Pemikiran Agribisnis Paradigma Baru Pembangunan Ekonomi Berbasis Pertanian. Edisi Ketiga Cetakan Pertama. Bogor : IPBPress

Saputro, N, Y dan Sediyono, E. 2019. Analisis Supply Chain Management (SCM) Komoditas Cabai Rawit Merah Di Kecamatan Getasan, Kabupaten Semarang. Seminar Nasional Teknologi Informasi Dan Komunikasi. 2(1): 267-271 
Setiawan, R., Susilowati, D., dan Sudjoni, M. 2020. Analisis Efisiensi Pemasaran Cabai Merah Di Desa Jetak Ngasri Kecamatan Dau Kabupaten Malang. Jurnal Sosial Ekonomi Pertanian dan Agribisnis. 8(23): 1-10

Sudiyono. 2004. Pemasaran Pertanian. Malang : Universitas Muhammadiyah Malang Press

Widayaningsih, N dan Priyono, R. 2012. Jalur Distribusi Dan Pembentukan Harga Komoditas Cabe Merah Di Purwokerto. Jurnal Eko-Regional. 7(2): 113-118 